\title{
Simultaneous rib osteosynthesis and thoracoscopic suturing of diaphragm at patient with severe chest trauma and respiratory insufficiency
}

\author{
A Benyan ${ }^{1 *}$, E Korymasov $^{2}$, S Pushkin ${ }^{1}$ \\ From 23rd World Congress of the World Society of Cardio-Thoracic Surgeons \\ Split, Croatia. 12-15 September 2013
}

\section{Background}

Severity of respiratory insufficiency at severe chest trauma is determined by many pathogenic mechanisms, including multiple rib fractures, ARDS, rupture of diaphragm. In such cases only internal pneumatic stabilization didn't solve that problem.

\section{Methods}

We present a case report of 42-years old man, who had sustained an injury result of pedestrian accident. The investigation revealed multiple fractures of 9 left ribs forming flail chest, rupture of left cupula of diaphragm with hemopneumothorax, left lung contusion and fracture of left clavicle. All this caused severe respiratory insufficiency.

\section{Results}

At first pulmonary ventilation was started and thoracocentesis with draining were performed. Then $4 \mathrm{rib}$ osteosynthesis using Matrix Rib, thoracoscopy with sanation of hemothorax and suturing of diaphragm, and osteosynthesis of clavicle have been done. After operation patient was 36 hours on assisted ventilation. There were no complications in postoperative period. Patient was discharged from hospital in satisfactory condition on 14th day after operation.
* Correspondence: armenbenyan@yandex.ru

'Samara Regional Clinical Hospital, Samara, Russian Federation

Full list of author information is available at the end of the article

\section{Conclusions}

Synchronous repair of injured organs of chest is indicated procedure for it prevents many severe complications including respiratory insufficiency.

\section{Authors' details}

'Samara Regional Clinical Hospital, Samara, Russian Federation. ${ }^{2}$ Samara State Medical University, Samara, Russian Federation.

Published: 11 September 2013

doi:10.1186/1749-8090-8-S1-P37

Cite this article as: Benyan et al:: Simultaneous rib osteosynthesis and thoracoscopic suturing of diaphragm at patient with severe chest trauma and respiratory insufficiency. Journal of Cardiothoracic Surgery 2013 8(Suppl 1):P37.
Submit your next manuscript to BioMed Central and take full advantage of:

- Convenient online submission

- Thorough peer review

- No space constraints or color figure charges

- Immediate publication on acceptance

- Inclusion in PubMed, CAS, Scopus and Google Scholar

- Research which is freely available for redistribution

Submit your manuscript at www.biomedcentral.com/submit
C Bïomed Central 